\title{
A Brave New World: the problems and opportunities presented by new media technologies in prisons ${ }^{1}$
}

Corresponding author: Yvonne Jewkes, Research Professor in Criminology, School of Applied Social Science, University of Brighton, Falmer, BN1 9PH; email Y.Jewkes@brighton.ac.uk

Co-author: Bianca C. Reisdorf, Quello Postdoctoral Fellow in Media and Information Policy, Department of Media \& Information of the College of Communication Arts \& Sciences, University of Michigan; email reisdo10@msu.edu

Keywords: prisons; technology; internet; digital inequality; digital exclusion

Word count 9206

\begin{abstract}
This article discusses the digital inequalities experienced by prisoners and the potential opportunities that providing 'new' media in prisons offers for offender rehabilitation and resettlement. Currently denied access to online and social media that most of us take for granted, and unable to communicate in ways that have become 'ordinary' in the wider community, it is argued that prisoners experience profound social isolation and constitute one of the most impoverished groups in the digital age. In prisons which provide selected prisoners some access to information and communication technologies, their high sociocultural status and consequent construction as a 'privilege' frequently results in them being used in the exercise of 'soft' power by prison officer gatekeepers. Moreover, when prisoners come to the end of their sentences, they not only are faced with prejudice and poor job prospects due to their criminal record, but their digital exclusion during a period of incarceration may have compound effects and lead to long-term and deep social exclusion.
\end{abstract}

\footnotetext{
${ }^{1}$ The authors thank the anonymous reviewers for their helpful and insightful comments on an earlier draft of the article.
} 


\section{Introduction}

Giving convicted prisoners access to digital media technologies is a highly sensitive and controversial issue, which has become defined and shaped by the expansion of neo-liberal policies, practices and discourses, communicated in large part by the popular media. As Western societies have moved from an inclusive welfare focus towards strategies of social control underpinned by the ethos of market competition and privatization, a somewhat paradoxical situation has emerged. On the one hand, those responsible for designing, building and managing prisons favour the incorporation of new communication technologies as a means of reducing operational costs. On the other, these same stakeholders are mindful almost to the point of paranoia about the extent to which prisoners' access to new technologies might be regarded as an unwarranted privilege and incur the wrath of the popular press.

In December 2015, however, widespread media coverage was given to the recommendation by Sir Martin Narey, former Director General of the Prison Service of England and Wales and advisor to the UK Ministry of the Justice, that prisoners should be given iPads in order to be able to stay in touch with family and aid rehabilitation and resettlement on release. Newspapers reported that the Secretary of State for Justice is giving the proposal careful consideration, and that other key stakeholders including senior personnel within the private custodial sector, support the idea. While online 'readers comments' accompanying the story were predictably scornful, the actual reporting of Narey's recommendation was uncharacteristically positive (or at least neutral) in most newspapers, perhaps because the Times' $\left(10^{\text {th }}\right.$ December 2015$)$ led on the story as part of a week-long, in-depth, investigative series on prisons, and the rest of the press followed the Times' lead in highlighting the benefits of digital media to prisoners' chances of successful resettlement. The publication five months later of Dame Sally Coates' review of education in prisons (Coates, 2016) gave further impetus to the drive for improved digital literacy among prisoners.

Against this backdrop, this article considers the potential impacts on prisoners of being denied access, or afforded only the most limited and constrained access, to technologies that most of us take for granted. We discuss the digital and online media that some prison inmates are permitted; the benefits and opportunities that Information and Communication Technologies (ICTs) bring; the extent to which they erode the 'totality' of the 'total institution'; and the ways in which ICTs are an effective resource in the exercise of 'soft 
power' by prison staff (Crewe, 2007). Like many other Incentives and Earned Privileges (IEPs), digital technologies function to enhance both decency and control, insofar as they eliminate many of the tensions of prison life, while providing officers with a 'carrot-andstick' at least as powerful as that provided by in-cell television - and one that many officers have similarly ambivalent feelings about in terms of their status as 'perks' that convicted offenders do not deserve. The paradoxes of having to satisfy commitments to the principles of less eligibility and public acceptability, while giving inmates a 'normal' experience in custody and preparing them for release and resettlement, are ones that have not yet been fully resolved, but will doubtlessly be at the forefront of Michael Gove's mind when considering the recommendations of Narey and Coates. Moreover, the utilisation of technology that allows savings to be made in the construction, design and operation of new prisons - another issue on Gove's agenda since his announcements in 2015 about ongoing prisons closures and their replacement with new, modern, fit-for-purpose facilities - brings further tensions concerning when is the 'right' time to bring prison inmates into the technologically advanced twenty-first century ${ }^{2}$. We suggest, then, that 'new' media give rise to a range of complex and contradictory issues that speak to age-old debates about what prison is for.

\section{Background to 'new' media technologies in prisons and to the study}

The impact of traditional broadcast media on prisons has been immense and few prisoners, prison officers and managers would argue against in-cell television having had a positive effect on prison regimes. Going well beyond resources for education, information and entertainment, or even 'electronic babysitters', in-cell TV has been shown to assist viewers in preserving a sense of their pre-prison selves and retaining connections to their families and communities in otherwise dis-identifying and isolating circumstances (Jewkes, 2002; Knight, 2016). For some prison populations, television has been identified as the most significant factor in protecting a sense of self and ontological security (Grant and Jewkes, 2014). Media technologies fundamentally challenge the historical meanings and functions of the prison as an archetypal 'closed', sequestered, and restricted space that assaults self and personhood. However, the notion of a 'total institution' is still seen as a desirable philosophy among some politicians and sections of the press and, although recently constructed prisons

\footnotetext{
2 If and when new media are permitted routinely in prisons, the drive is likely to come from education. One technology-driven initiative already in operation and under ongoing development, is the Virtual Campus, a secure intranet with potential to support education and other initiatives. However, in our study it was roundly criticized for its ineffectiveness by everyone who mentioned it; and has been condemned by others for its perceived severe limitations (Champion and Edgar, 2013; Coates, 2016).
} 
share an outward appearance with hospitals, colleges and leisure centres, there remains a pervasive cultural expectation that, behind those benign facades, prisoners will nonetheless feel sequestered from society and removed from stable social arrangements (Goffman, 1961). 'Total institution' is, then, a term whose topic is not really institutions but confinement (Sparks et al, 1996: 60). In its evocation of the 'role-stripping' procedures of bureaucratisation, the inherent deprivations of incarceration, and the substitution of institutional values for human ones, 'total institution' remains a compelling empirical description whose objective is partly achieved by the curtailment of access to the forms of communication, personal interaction and social networking that the rest of us enjoy. So just how isolating is the modern prison?

In the influential No Sense of Place (1985) Meyrowitz described how television, computers, telephones and radio, democratise and homogenise places by allowing people to experience and interact with others in spite of physical isolation. 'The walls of the mightiest fortress', he said, 'no longer define a truly segregated social setting' if any form of media is present (1985: viii). Two decades later, Meyrowitz returned to the subject, noting this time that the significance of locality persists even in the face of massive social and technological changes' (2005: 21; our emphasis). For some critics (e.g. Moores, 2007), this shift of focus from global to local appears inconsistent, but arguably no setting illustrates the veracity of Meyrowitz's seemingly contradictory position more coherently than the prison. Certainly, digital media undermine the traditional relationship between physical context and social situation to a degree that even Meyrowitz may not have foreseen, writing No Sense of Place a decade before the World Wide Web became publicly available and two decades before the first smartphone was unveiled. When we use the internet we are no longer ' $i n$ ' our physical setting but can escape to a 'generalised elsewhere' of distant places and 'non-local' people (Morley and Robins 1995: 132), which is arguably precisely what makes the idea of digital media in prisons so unpalatable to its critics. The interactivity and 'freedom' offered by the internet conflicts with commonplace ideas about incarceration being a time of isolation, solitude and penitence, as well as retribution, material hardship and suffering. However, the local physiognomies and 'affects' of incarceration are arguably more significant than most other contexts in inhibiting new senses of identity and place in the so-called 'global village' (Meyrowitz, 2005). ICTs allow prisoners to transcend time and place, but only in ways heavily circumscribed by the prison building, the locale in which it is situated, and the prison staff and managers who control almost every aspect of prisoners' everyday lives. Hence, 
despite the belief of many of us that we could no longer function (as students and scholars, as members of a workforce, as informed citizens, as social actors - even as 'friends') without our internet-enabled mobile devices, individuals in prison, who do not have unfettered access to these technologies, are not only more 'place-bound' than most but are entirely excluded from participation in what now constitutes 'normal' social life.

Although intended to be primarily a broad and discursive treatment of the issues that this form of social exclusion gives rise to, the article will draw on our observations at five staterun custodial sites; four in Northern Ireland (NI) and one in England. We were invited to spend two days visiting the four institutions in NI by the Director General of the Northern Ireland Prison Service (NIPS), who had heard about our research and was both intrigued by our study and also keen to share with us current ICT provision and future strategy for digital access in $\mathrm{NI}$ prisons. The one-day visit to the prison in England came in response to a request for information by the authors to the prison governor. In all cases, then, the approaches were somewhat ad hoc and we had to be responsive to invitations arranged at short notice. Because of this, we were not able to gain full ethics approval in advance of the visits (we applied retrospectively), and consequently refrained from collecting 'hard data'. To clarify further, we did not audio-record any of the sessions with prisoners, prison staff and prison governors, and we did not take notes in the prisons. At the beginning of each meeting with prisoners, we explained that their participation was voluntary and confidential and that no one should fear repercussions for participating (or not) in the discussions.

The prisoners we spoke to all were in groups of between five and eight, with one larger group (of adult males) of 15 , and the discussions took place in classrooms or association rooms. In four of six cases, we were able to talk to groups of prisoners without any prison staff present. In the other two instances, at least one prison officer was present. Overall, we spoke with around 40 prisoners across the various groups. Because of the limitations on data collection, our analysis and discussion will mainly rely on our observations and impressions that we wrote down after leaving the prisons. These prisons can be considered at the forefront of innovation in at least actively considering the options and the potential positive impact that (some) Internet-enabled technologies could provide to their prisoners in their efforts to rehabilitate. They are not necessarily, then, 'representative' of prisons in the UK. 
The establishments we visited were: a prison for sentenced and remand women (notable for its trial of Skype at the time we visited); a facility for Young Offenders that has recently been rebranded a secure college with a focus on education and rehabilitation (and where inmates are no longer referred to as 'Young Offenders' or 'prisoners', but 'students'); a training prison holding medium and low security risk adult men (where the latter were permitted to use Skype); an open prison with a resettlement regime, where we observed two IT classes; and a Working Out Unit for prisoners approaching the end of long-term sentences who were experiencing many 'new' technologies for the first time on their temporary release days in the local community. The prisoners we observed and talked to were demographically varied, and the purpose of this article is not to discuss in detail how differentiated groups of prisoners use digital media differently. Clearly, prior experience, individual competence, social network and prisoner habitus will be among the factors that structure desires for, or ambivalence towards, the mediated prison. Our visits, however, were primarily intended as an exploratory, scoping exercise to find out what are the most salient issues, concerns, problems and opportunities pertaining to prisoners' usage of new media technologies generally, both while in custody and as they transition from prison to resettlement in the community on completion of their sentences.

The visits allowed us to observe usage of new media, talk to staff and prisoners about their implementation, and share ideas and information with senior personnel about small improvements that could be made that would have a significantly beneficial impact on the quality of life for prisoners. In addition, we were granted the opportunity to talk to a number of prison officers, prison governors, and prison IT teachers. Our conversations were mostly one-on-one and informal and took place in staff offices or over lunch or coffee. Once again, we did not take notes during the conversations, but instead relied on our observations and notes written down after leaving the facilities. The small number of direct quotes that appear in the following sections are from prison service or National Offender Management Service (NOMS) personnel interviewed for a separate study led by one of the authors, for which full ethical approval was granted ${ }^{3}$.

\section{Disconnect between prison and society}

\footnotetext{
${ }^{3}$ ESRC Standard Grant ES/K011081/1 "Fear-suffused environments" or potential to rehabilitate? Prison architecture, design and technology and the lived experience of carceral spaces' (with Dr Dominique Moran, GEES, University of Birmingham and Dr Jennifer Turner, SASS, University of Brighton).
} 
During our visits to the five prisons, we frequently heard that decisions regarding what media hardware, software and services should be permitted in UK prisons must pass the 'public acceptability test' or, as it is more commonly called among prison staff and managers 'The Daily Mail test' ${ }^{4}$. At the prison college, the fact that subscription satellite TV services were withdrawn in favour of free-to-air digital channels (because it was deemed that the former would incur the wrath of the public, but that the latter were acceptable), meant that some local TV channels were lost and also that the prisoners were denied access to broadcasts of sports events. Mindful of the centrality of sport to many young men's lives and identities, some staff did what they could to fill the gap in provision. For example, a young man who had been a promising Gaelic footballer prior to his conviction, was brought in videotapes of matches a few days after they had taken place by a member of the prison chaplaincy.

This is but one example that underlines the proposition that lack of access to new media constitutes a 'distinctive pain of modern imprisonment' (Johnson 2005: 263) and creates a new level of disconnection between prison and society. But it also illustrates a somewhat paradoxical aspect of media consumption in the twenty-first century. Many of us now watch broadcast media 'on the go' via apps such as BBC iPlayer, Sky Go, Netflix and YouTube. We can speed up, slow down, suspend, repackage, reorder, repeat and share our mediated experiences with friends and strangers. We can consume media outputs in our homes, our gardens, in bars, on trains, or any manner of other public and private spaces. None of this experience is available to prison inmates, whose temporal and spatial experience is traditional, linear and confined. On the other hand, for significant events (including sports events) we may choose to put aside our phones, tablets and laptops and return to traditional modes of viewing, i.e. television. Watching 'big' events on 'big' screens with a group of others - whether at home or in public places such as sports bars - makes individuals feel connected to a wider community and forms long-term collective memories, 'marked up not only on the public calendar of "history" but also on the private calendars of people's lives' (Scannell, 1996: 91). Prisoners are denied this opportunity too. As wellmeaning as it is for the prison chaplain to record Gaelic football matches for the young man

\footnotetext{
${ }^{4}$ Introduced in 2009 by then Home Secretary Jack Straw, to ensure all activities in prisons are 'acceptable, purposeful and meet the public acceptability test', the new ruling followed negative newspaper reports about a stand-up comedy class at a high-security prison in England. Among the most disparaging critics was the Daily Mail; a middle-market, tabloid newspaper renowned for its right-wing political views and prurient celebrity gossip. In Northern Ireland mention was made of 'the Nolan test', referring to the outspoken and influential radio and TV presenter Stephen Nolan.
} 
who once aspired to make it his career, solitary participation in a match days after it took place barely constitutes participation at all ${ }^{5}$.

Unsurprisingly, then, many prisoners believe the restricted access they have to communication technologies, and in particular the almost total absence of computers and internet access, is a form of censure that reduces them to second-class citizens in the Information Age (Johnson, 2005). The senior personnel we spoke to in both public and private sector corrections were sympathetic to this view. All spoke of the need to bring prisons into the twenty-first century and introduce into the custodial estate the kinds of media technologies now deeply embedded in the rest of society; not just for education and training purposes, but also for leisure and pleasure. The infrastructure is being put into place; every new-build prison in the UK is now fitted with 'Cat 6' Ethernet cables designed for use in high-speed gigabit networks. However, the technology is not installed in such a way as to make it immediately usable. Put simply, cables are hidden and sockets are covered until such time as, in the words of one prison service manager interviewed in April 2015, 'there is sufficient public appetite to allow prisoners access to Skype and things like telehealth'. Given recent positive changes in political policy and rhetoric, that time may be nearer than could have been anticipated even a year ago.

\section{Technologies that are already transforming the carceral environment}

Despite the caution that surrounds prisoners having any form of personal, unmonitored media, other technologies are being introduced, including 'smart' touchscreen kiosks, on which prisoners can book family or legal visits, make medical appointments, order their 'canteen' (items from the prison shop, including food and tobacco) and, in some cases, choose their meals. The kiosks use a combination of PIN input and biometric scanning to login. Driven by private sector providers, kiosks are 'sold' to the government as being integral to a 'responsible prisoner' strategy, helping prisoners to lead independent lives in preparation for their release. They are, then, part of the armoury of the late-modern prison described by Crewe $(2007,2009)$ that has created a shift in governance, and refashioned power and control from a coercive model to one that operates via self-interest and selfregulation. If prisoners do not receive family or legal visits, or get a doctor's appointment, or

\footnotetext{
${ }^{5}$ The 'emailaprisoner' scheme is another example of media in prisons being a pale imitation of media generally, with prisoners having to compose handwritten replies to emails they receive, which are scanned and returned electronically (Knight, 2015). In an era of instantaneous communication, the application of the scheme appears so unwieldy and impractical that none of the prisoners we spoke to participated, preferring instead to use the few phone calls and visits that they were permitted each week.
} 
receive their canteen (items such as tobacco, chocolate and phone cards), they only have themselves to blame. Following Garland (1997) and Foucault (1977), Crewe suggests that this responsibilization model does not constrain so much as 'teach' the offender to engage with institutional goals. By using kiosks to facilitate many of the most important and meaningful exchanges that a prisoner has to make, technology is being harnessed to encourage the prison inmate to become 'an entrepreneur of his own personal development, rather than an objectivized or infantilized client upon whom...solutions are imposed' (Garland, 1997: 191). In Foucauldian terms, power and governance now operate in ways that feel 'light', self-rewarding, non-corporeal, autonomous and anonymous (Foucault, 1977; Crewe, 2007).

Technological advancements have, then, divested prison officers of some of their authority, pushing power both upwards (to executive level managers, governors and middle-managers, including those providing healthcare, education etc.) and downwards to the newly selfempowered prisoner. Privately, some of the senior personnel we spoke to (at government level and within the UK prison services) expressed concern about the extent to which such technology reduces the interface between prisoners and staff and can result in longer lockup times and fewer officers. Requiring prisoners to take responsibility for aspects of their lives previously administrated by officers potentially frees up significant periods of staff time formerly spent on form-filling and, in theory, this newly acquired time can be spent on more meaningful interactions with prisoners. Whether this always happens in practice is a moot point.

Another issue raised by senior HM Prison Service personnel who were sceptical about the installation of kiosks - and concomitant expectations of prisoners being self-managing entrepreneurs of their own day-to-day lives - was the high rates of illiteracy and social marginalisation experienced by prisoners prior to entering prison. As one senior advisor to NOMS put it, 'the idea that these guys are queuing up to get their hands on new technology is way off the mark. Some of them are quite averse to anything new-fangled. It scares the living daylights out of them'. This may be true, particularly of individuals who have been in prison for a very long time and therefore have not grown accustomed to the creep (and latterly, the acceleration) of the digital society. But for many prisoners, innovations such as digital kiosks reduce some of the stresses and tensions of life inside. For example, one prisoner in a Category D open prison told us that kiosks had led to unprecedented 
independence and autonomy in those privately run establishments that had installed them and circumvented potentially frustrating interactions with staff who were too busy or insufficiently motivated to deal with prisoner requests in a timely manner. He said that new technologies 'normalise' the prison environment - yes, they entail interacting with a machine rather than a person but, in his opinion, that simply prepares the prisoners for real life outside, where it is becoming increasingly uncommon to have face-to-face exchanges in most service industries.

But here we see a new form of 'digital divide' emerging between 'new' prisons and 'old' prisons (where it may not be physically possible to create the infrastructure required for a digital environment), and between privately managed facilities and those in the public sector. Private contractors see it as part of their role to bring in innovations that lead to greater efficiency and effectiveness, and improve prisoners' quality of life and chances of resettlement. Indeed, they may be subject to financial penalties if they fail in these regards. Establishments run by Her Majesty's Prison Service, on the other hand, can seem 'stuck' in their Victorian pasts, unable (or unwilling) to embrace change. As Meyrowitz reminds us, this can make the issue of which prison someone is sent to even more of a lottery than it is already (with different prisons providing varying levels of education and training, accredited and non-accredited behavioural programmes, gyms and sports facilities, and so on). Now, along with the physical variables of 'high security' and 'low security', and the vagaries of what may or may not be available in any given establishment, we must add the communication variables of 'high information' prisons versus 'low information' prisons (Meyrowitz, 1985: 117-8). The use of digital media has thus led to a redefinition of the nature of 'imprisonment' and to a de facto revision of the prison classification system.

Even within a single establishment, the use of media (traditional and new) as central rafts of the Incentives and Earned Privileges (IEP) scheme means that prisoners housed in different parts of the prison will have quite divergent experiences of technology. Perversely, some of the most 'privileged' prisoners we met who were on 'Enhanced' status are living in low security accommodation units (actually, former Nissan huts) and only have access to outdoor telephones, meaning that they have to line up outside waiting their turn to reach the head of the queue and make their call. For them, in-cell phones were a highly attractive proposition, even though they have limited access to Skype (discussed below). Also pioneered in privately managed prisons, in-cell phones have long been held to have 
significant advantages over traditional, shared landing phones because they eliminate the need for large numbers of prisoners to congregate in small spaces, while waiting their turn to use a communal phone; a known 'flashpoint' where bullying and assaults can occur (Jewkes, 2002). At the open prison we visited one prisoner said that in a previous establishment he had been held in (a privately operated, medium-security prison) he had valued the in-cell phones provided because his mother was a shift worker and was rarely available to take calls from shared phones on landings at the permitted time (usually a period of about two hours in the evening). Having a private phone on which calls could be made at any time allowed him to maintain family contact in a way that was no longer available to him at the Category D, low-security prison he had moved to.

The effects of two seemingly contradictory positions - the denial of some communication technologies and reliance on others - have not yet been empirically tested. Despite institutional resistance, all the managers we met spoke candidly about the absurdity of modern-day, publicly-funded institutions being reliant on paper-and-pen communications and old technologies such as videos and DVDs. The irony of an ICT tutor trying to get hold of the Encyclopaedia Britannica on CD-ROMs in an age of Wikipedia was not lost on the prisoners in one of the classes we observed. Even for prison managers and staff, communicating by email, text and Skype is not commonplace, and two senior personnel spoke of their frustrations about firewalls that do not allow emails to be received, when containing words including 'sex' (making communications about, for example, Sex Offender Treatment Programmes problematic). Others commented that the lack of communications hardware in prison can make non-uniformed staff feel unsafe; they can request a personal alarm but are not issued with radios and know that if put in a dangerous situation by a prisoner, their links to the 'roaming officer' on duty, let alone the nearest police station, will not result in a rapid response.

The relatively remote location of two of the prisons we visited was highlighted as a key barrier to technology. At one, discussions about the security implications of allowing prisoners to use internet disabled tablets and games platforms that could, with some ingenuity, be illicitly converted to internet enabled hardware, was met with a snort of derision by the prison governor who said that there was no reliable broadband connection for several miles. Nonetheless, the pervasive fear that someone could convert an internet disabled device into one on which they could access pornography or contact their victim(s) 
was communicated in nearly all the conversations we had with prison staff and managers. One prison ICT tutor, musing on the fact that the OLASS (Offenders' Learning and Skills Service) education that he is required to provide is woefully inadequate for the mostly young men in his class, said: 'they say "why are you teaching me Word? What's Word anyway? I could strip this computer bare and put it all back together, and improve its functioning, in the time it takes you to teach me Word"'.

\section{What happens 'afterwards'?}

Not all prisoners, however, are comfortable with new media. The aversion of some (especially older and long-term) prisoners to digital and internet technologies is unsurprising and is consistent with broader patterns in society. In an age when internet and touchscreen technologies are constantly promoted as being socially desirable, ubiquitous even, 'nonusers' are often loathe to admit their non-engagement and men particularly struggle with owning up to their lack of competence (Reisdorf et al, 2012), seeing this skills deficit as a threat to their masculinity and status as 'masters' of their lives. In their comparative, qualitative study of 'living offline' in the UK and Sweden, Reisdorf et al (2012) found that it was not simply lack of economic resources that resulted in non-engagement with internet technologies. Many people who are not economically marginalized choose not to engage with the internet because, for example, they have lifestyles, hobbies or jobs that can be conducted entirely offline (e.g. a career as a professional athlete or a passion for playing a musical instrument), or simply an ideological resistance to the 'information society'. They could not envisage how the internet would add value to their lives - or at least not sufficient value to go to the effort of learning a new skill. However, when the researchers delved a little deeper, many of these same participants expressed discomfort with the technology itself and relied on partners, family members and colleagues to act as ICT 'proxy-users' on their behalf. Others were unable to type or text because of illiteracy, visual impairment or simply an aversion to the 'over-complicatedness' of computers and mobile phones. Of those who reluctantly had overcome their anxieties, many had done so because their children had persuaded them.

All these concerns, impediments and limitations to technology usage are magnified in the prison environment amongst a population that is overwhelmingly male, suffers disproportionately from all forms of social exclusion, and ages more quickly than the population at large. Unsurprisingly, then, while some of the younger individuals talked 
excitedly about 'catching up' with the latest smartphones and apps when they are released, and the women all said the thing they missed most in prison was Facebook, many of the older male prisoners - particularly those who served long sentences and are now being prepared for release with home visits and work in the community - were apprehensive about engaging with digital media. We discussed their thoughts about re-entering a world that, from a technology standpoint, is virtually unrecognizable from the one they left fifteen, twenty, or more, years ago. They struggled with terminology, sometimes referring to 'abs' or 'amps' when they meant 'apps', and they spoke of their discomfort at having to ask family members to show them how to use phones and tablets. Many reported that the omnipresence of new media technologies constantly reinforced feelings of stupidity, difference and marginalization from the 'normal' world and even within their own families, reflecting broader anxieties of non-users (Reisdorf et al, 2012). Several narratives were infused with a mixture of comedy and embarrassment as prisoners now eligible for home leave told of how they had to ask their siblings, children, nieces and nephews to show them how to use mobile technologies. They mimed their clumsy efforts to master tiny keyboards, swipe tablet screens and understand when to use the keyboard and when to touch the screen - to much laughter and nods of recognition from other participants in the discussion. Most of these men appeared to have families they were returning to after serving a life sentence. They expressed frustration at not finding ICT skills intuitive to them and said their relatives had endless patience in showing them how to do it, and were grateful for such tuition in the privacy of the home.

These prisoners' greater anxieties were reserved for new technologies in the public sphere and commonly expressed fears among non-users in society at large were greatly exacerbated by having been almost entirely cut off from that society for a significant period of their lives. Internet-enabled computers in libraries, touchscreen machines for buying train tickets, automated banking and self-service checkouts at supermarkets were all heatedly discussed. The latter was the source of most consternation because the men had already experienced checkouts where you scan barcodes and put your money in a machine, rather than giving your shopping and your cash or credit card to a person at a till, while on home visits. For these prisoners trying to make the transition from two decades inside to life on the outside, the mixture of technology that can be difficult to use, the fear of appearing stupid and drawing attention to themselves (and perhaps signaling in the process that they have been away from society for a long time) and the lack of a 'real person' to interact with, 
led to an animated discussion about their feelings of being stuck in a former time; in fact, two of the men described themselves as 'cavemen'.

\section{Skype and mobile technologies - a 'step forward'?}

One technology that appears to offer much to prisoners, particularly those for whom family visits are difficult or impossible is Skype; free-to-use internet software that permits video chats via a webcam. Skype was being piloted in two of the facilities we visited with mixed reactions from the prisoners. Senior personnel within the prison service had told us of the success of its implementation at Christmas time when prisoners were able to watch their children unwrap their presents. A male prisoner told us that it was invaluable for keeping in contact with his family who live abroad, while another said that it had made a huge difference to his quality of life and that it was not just immediate, short-term benefits that it brought, but that the positive feelings initiated by a Skype call with his family was a 'high' that lasted for several days.

The implementation of Skype was not without its problems, however. In the women's facility, the computer was placed in the reception 'because that's where the cable is' (prison ICT manager), but this area was only intermittently staffed, meaning that prisoners could not use Skype very often ${ }^{6}$. In addition, its implementation was intended (by the prison's governor) to be a bonus; a supplement to the actual, physical visits the prisoners were entitled to. But officers staffing the unit had interpreted it as a substitute, so that a prisoner who used Skype for a family call then had to forfeit one of her actual visits. In the men's facility, Skype's potential value was also compromised by prison staff. Prisoners complained about a lack of privacy because the monitor was in a room adjacent to the staff office and the walls were thin. Moreover, after facilitating the initial link-up, officers were continuing to watch the two-way interaction between the prisoner and their relative(s) on their own monitor in the staff office, despite this being contrary to prison policy on monitoring phone calls generally (which is restricted, randomly applied and predominantly intelligence-led). The passing comment from an officer to a prisoner following his weekly Skype call home 'that's a nice wee dog you've got there' - was felt to be overstepping a boundary. Even more problematic for some was the fact that prisoners who entered the office or looked through the glass door from the corridor could see the computer screen. For some, the realization that fellow inmates could see their homes, partners and children was a barrier to using

\footnotetext{
${ }^{6}$ Champion and Edgar (2013) found similar limiting factors with access to the Virtual Campus, with computer terminals placed in locations that prisoners had little or no access to.
} 
Skype and, after initial enthusiasm when it was first introduced, they abandoned it and went back to queuing outside to use the payphones.

In-cell phones were widely praised by all prisoners we talked to, with some willing to be accommodated in double cells if they came with a personal phone. Currently, the phones that have been installed in (mostly private) prisons have handsets that look like conventional landline telephones. They are pre-programmed with approved numbers and can only be used for outgoing calls, or for incoming calls from prison services. So, for example, a prisoner is not allowed to receive a call from a relative on the outside, but might be contacted by the prison healthcare centre with the results of a medical test. Privately-operated prisons are able to test such innovations while the Ministry of Justice watches on, and in the near future, some private contractors report that they will introduce in-cell phones that look more like mobiles, which will allow two-way texting; the first time that direct, personal communications will be able to be received by prisoners from the privacy of their rooms (interview with Operational Development Director, G4S).

New media in prisons may become common relatively soon, then, though not for humanitarian reasons or in an effort to 'normalise' prison regimes, but because they can reduce staffing and other operational $\operatorname{costs}^{7}$, and give managers and staff some control of the spread of technology that is happening anyway. Designed, in part, to try and reduce the desirability of illicit mobiles, in-cell phones appear to offer a solution to some of the issues around privacy and maintenance of family contact already described, while also having the advantage that they can be managed, to a degree, by prison security personnel. The telephone numbers that they are pre-programmed with are vetted and authorised, the phone is activated with biometric data, and security officers can listen to calls if they have a legitimate concern. Their successful implementation by the private sector means that public prisons will surely follow suit, although some senior prison service employees expressed unease that bad news communicated from outside (e.g. the telephonic equivalent of a 'Dear John' letter) could leave the recipient alone and in a heightened state of anger or anxiety, with no officers able to observe and intervene. Other senior personnel raised concerns about the potential for prisoners to harass or control partners and family members from within the privacy of their cell. Anecdotally, several prison managers told us that

\footnotetext{
${ }^{7}$ Tablets will be installed in all prison cells in The Netherlands over the next two years. At a EuroPris 'Prisons of the Future' conference held in The Hague (March $2^{\text {nd }}-4^{\text {th }}$ 2016) attended by one of the authors, there was much discussion about the fact that for all its perceived benefits, it would result in staff cuts and longer lock-up times as prison libraries are closed in favour of e-books and downloadable education material.
} 
longstanding campaigns of domestic abuse against partners were reignited when in-cell phones were introduced.

\section{Discussion}

From the discussion so far, it can be seen that, despite historic political resistance and perceptions about the limits of public tolerance, new media technologies are available in prisons and are transforming carceral space. As with all measures that have both enabling and controlling properties, however, the politicized agenda of security and risk management that characterizes the penal system has resulted in negative as well as positive responses to digital media. Very long-term prisoners who entered custody in a pre-internet age felt that they were inadequately prepared for life on the outside. They said they would like to be shown how to use personal mobile devices, and receive some training in using the kinds of automated, biometric, touchscreen and barcode scanning equipment they will encounter in everyday life, well before they reach the point in their custodial journey where they are permitted home leave and to work in the community. 'Too little, too late' was the general verdict on the prison service's policy of allowing them a basic mobile phone with no internet capability when they reached the Work Out Unit. There was a sense, however, that staff in this Unit were sympathetic to the prisoners' predicament and were doing what they could to assist the men in their preparations for release into the brave new world of technology; both rhetorically and practically. For example, during our discussions, they gently countered the ideological resistance of one individual who proclaimed himself a 'people person' and said he would continue to have nothing to do with technology when he was released, and a manager in the unit described how he had, on one occasion, brought in a tablet to show the prisoners how swipe-screen technology worked.

In some of the other facilities we visited, there appeared to be another story to tell about the ways in which new technologies are perceived by staff and implemented 'on the ground'. The trial of Skype provides an interesting case study illustrating the potential disjuncture between attempts by prison services and management to re-legitimate the prison through strategies that normalise prison life and assist inmates in maintaining contact with family and, ultimately, making a successful transition from prison to society; and staff practices, which thwart these efforts and amount to unauthorized exercise of 'soft' power (Crewe, 2007). Some of the obstacles may be put down to a lack of creative thinking; for example, Skype being available only in a restricted area because 'that's where the cable is'. 
Some may be explained by carelessness or lack of thoughtfulness, e.g. the Skype monitor in the men's unit being in an office-style room with hard fixtures and fittings and a view (from the relative's perspective) of the prisoner sitting in front of a filing cabinet and a blank wall, the other side of which was a watching prison officer (and, potentially, prisoners). Some barriers to take-up of new technologies might be the result of poor communication; insufficient clarity that Skype contacts were an additional service, not a substitute for, 'real' contact visits. On the other hand, all these failures of implementation might be regarded as consequences of the micro-culture of uniformed prison staff, who firmly uphold the principles of public acceptability and less eligibility, supported by macro policies and procedures which are risk-averse and resistant to change.

In these small but significant ways penal power, as traditionally conceived through techniques of governance and managerialism, is reconstituted in the flows of power on the landings (Crewe, 2007). New media technologies - widely regarded as privileges that are highly prized by an undeserving underclass - become the site of more complex ideological struggles and prisoner orientations, including resistance, acquiescence, normative commitment and 'resigned fatalism' (Crewe, 2009). What was interesting to observe in this small study was the absence of any challenge to the regressive media environment that the prisoners found themselves in. Aside from occasional comments such as 'why aren't we allowed iPod Shuffles?', most prisoners seemed remarkably acquiescent about their 'caveman' status. They were resigned to the apparent inalterability of the fact that new technologies are part of the arsenal that prison staff now have at their disposal when exercising their authority. In fact, in all the groups we spent time with, opinions were voiced that conformed to prevailing ideas about less eligibility and the idea that, as convicted offenders, they were 'undeserving' consumers of new media. Such expressions of support for these dominant ideologies are not uncommon among prisoners who have embarked on some kind of self-improvement, e.g. substance misuse programmes, where the desire to change can border on evangelistic (Crewe, 2007), but they are less evident in relation to goods and services, including traditional media, which, on the whole prisoners view with a sense of entitlement (Jewkes, 2002). Yet the frequency with which sentiments of moral selfreproach were expressed in relation to new media suggests that their status as luxuries rather than necessities prevails among both senior prison officers and the prisoners themselves. This is problematic in an era where ICT and new media skills are considered key components of a rounded skills-set that allow a successful participation in society (Selwyn, 
2004), and where less use and more narrow use are associated with digital inequalities and being 'left behind' (Zillien \& Hargittai, 2009). Commentators note that ICT deprivation must be considered equivalent to other social deprivations, such as low income, unemployment, low education, poor health and social isolation; and that 'to consider ICT deprivation as somehow less important underestimates the pace, depth and scale of technological change (Helsper, 2011; Helsper and Eynon, 2013). Moreover, the compound effects of ICT deprivation in combination with other social deprivations, arguably leads to loss of confidence and social capital. A modern 'pain' of imprisonment thus becomes long-term deep exclusion from society.

The introduction and implementation of digital media technologies in prisons is, then, a complex issue and a mixed picture has emerged of availability and usage. Access currently appears to be dependent on which security category of prison an individual is held in (and in some cases, which wing $\mathrm{s} /$ he is on), where that prison is located, and whether it is publicly or privately operated. In addition to these formal structures, the informal culture of a prison (or wing/unit), the management style of the senior officer in charge of that space, and the personalities and predilections of the officer who happens to be on duty at any given time, all influence the success or otherwise of new media in prison. One consistency amidst this patchy and unpredictable access is prison education, which provides basic level computing skills (Word, Excel and PowerPoint) to students across the prison estate. Although the quality of teaching is as variable as it would be in any classroom setting, even the most skilled and passionate tutors are severely hampered by the technology at their disposal which, according to one ICT tutor we spoke to, was eight-year-old software and thirteenyear-old hardware. That said, the ICT classes we observed demonstrated that tutors do their best to make the basic skills that OLASS requires them to teach relevant and engaging to students by, for example, setting them tasks such as inputting Premier League football teams into a spreadsheet and calculating how the league tables changed according to wins and losses (and the points associated with this). Yet some prison teachers seem to be in denial about the usefulness of the skills they are required to pass on or they have bought into institutional discourses about. The frequent refrain we heard one tutor direct to her students - 'if you want to start your own business when you get out of here...' - had a hollow ring to it, given the very low-level, and somewhat outdated tasks they were being set - especially at a time when small businesses that do not have well-maintained social media sites are almost bound to fail (Schaupp and Bélanger, 2014). As another prison tutor told us, 
somewhat sardonically, word-processing a CV that contains little more than the qualifications gained in prison (accredited programmes, such as anger management and alcohol awareness) is not helpful in the quest for gainful employment. How much more useful might it be to teach prison inmates business start-up skills, how to build a website, or even how to establish an eBay shop?

Among some uniformed prison officers, responsibility for managing the prisoner-technology interface was rather more ambiguously framed. At the male, low-security unit where Skype had been introduced, staff showed us the rota on which prisoners sign up for a 15-minute session. They said if a prisoner wanted to Skype for longer, he could do so if no-one was scheduled immediately after him. In practice, prisoners said that some officers were strict about the 15-minute rule and would pull them off even if no-one else wanted to use it. One individual described how he had been allowed to Skype his daughter on Boxing Day. The link had taken a while to establish and his little girl was initially overwhelmed by the technology and shy at seeing her father at Christmas for the first time. By the time she relaxed and got used to it, the permitted timeslot was nearing its end. She had to go to the toilet and when she returned, the session was over and her father was being asked to return to his cell. With all these problems of privacy, personal security and exertion of control by officers, it is perhaps little wonder that the rota had few names on it. Everyone agreed that the idea of Skype for prisoners was an enlightened, humane and well-meaning intervention by senior management, but that its implementation by prison officers could have inhumane implications for prisoners and their families.

\section{Conclusion}

The reasons why prisons have been slow to implement new media technologies are complex and multifarious. Discussions at executive level are not about less eligibility and undeserving outcasts. In some cases, they may be underpinned by genuine fears about prisoners' abilities to cope with and adapt to the brave new world of a media-enriched prison environment. Cost is a factor and, to some extent, short-term, cost-benefits thinking still dominates, especially within the public sector. The language of economics, effectiveness and efficiency remains, however, salient right across the prison estate and is favoured over more normative, long-term strategies to equip convicted offenders with the skills and competencies they require to participate fully in society on release. 
But while senior managers acknowledge that many prisoners' relationships to new media technologies is shaped by pre-prison experience of the digital mediascape, and that the access they are given to new media while serving their sentences is crucial to their prospects for successful rehabilitation and resettlement post-release, the discourse in which debates about prisoners and new media technologies are overwhelmingly situated is that of security and risk. More often than not, the introduction and application of new technologies are thwarted by security personnel who are highly resistant to finding solutions to potential security breaches, or even to confronting evidence that their imagined security fears are unfounded, and prohibit technologies as a matter of course. Several prisoners and managers reported that the word 'security' simply closed down all conversations about digital technologies in prisons.

The biggest fears surrounded online media, but even technologies that are not internetenabled, but could potentially be converted, were vetoed by security officers because, as one of them put it, 'you'll always find some bright spark who can take an iPod or games console and convert it to watch pornography or contact people outside that they shouldn't'. This is a deeply entrenched and oft-repeated view ${ }^{8}$, which underlines current rationales for punishment and belies an overt risk-aversion. It is rarely, however, balanced by a desire among prison service personnel to exploit the full capacity of the digital prison. As a means of communication, accessing public services, research, education, banking and employment, the potential of ICTs is simply not even being systematically or strategically addressed (Champion and Edgar, 2013). Further, the 'inarguable' justifications for limiting prisoners' use of new media and the refusal of security managers to countenance ways in which technology could be made safe (for example, allowing Wi-Fi connections and then 'whitelisting' approved sites) only adds to the inequitable and unjust landscape of media flows that maintain existing relationships of power within society. Opposition to the idea of installing and administering ICTs in prisons by those with the power to grant them also speaks to a deeper, underlying retributive philosophy. Traditional structures of authority are highly resistant to the introduction and spread of digital infrastructures on the grounds that they carry risks of inappropriate networking, prisoner organization, resistance, mobilization, and access to 'risky' content. But beneath such pragmatic worries lies an arguably deeper epistemological threat to the physicality of the prison environment and experience. That is

\footnotetext{
8 The Coates review quotes a prison learner: 'There is a mentality around IT in prisons that assumes that if prisoners are given a paper clip and a piece of tin foil, they will immediately build a modem and use it for illegal purposes' 92016: 44).
} 
to say, the appearance and functionality of digital media 'unborders' the tightly policed and defined margins of prison space. Flows of interactive data, and the meanings that are ascribed to them, are much harder to administer and control than the relative fixivity of the prisoner body (Foucault, 1977).

Yet, even if only for economic expedience rather than any rehabilitative purpose, it may not be too many more years before England \& Wales follow the lead of some of its near neighbours in Europe, where prisoners will soon be connected to a secure digital platform via laptops (e.g. Belgium) or tablets (e.g. The Netherlands) in cells. Future research may, then, explore the nuanced meanings that prisoners attach to 'new media' devices (e.g. whether they empower individuals or limit personal growth), in similar ways to the complex and frequently conflicting meanings ascribed to traditional media in prisons (Jewkes, 2002). Sir Martin Narey has paved the way for discussion about iPads in cells and Dame Sally Coates has recommended strengthening the digital infrastructure to support new ways of learning in prisons, but it is likely that the first contractor who introduces interactive, digital media into custodial environments (especially for uses that go beyond education and into the realms of leisure and pleasure) will be regarded as courageous or foolhardy. However, until it happens, a profound and unprecedented level of disconnection will continue to exist between the prison and society, leading to deep, long-term social exclusion of individuals who have been sentenced to custody.

\section{References}

Champion, N. and Edgar, K. (2013) Through the Gateway: How Computers Transform Rehabilitation, London, Prison Reform Trust. Available online at http://www.prisonreformtrust.org.uk/Portals/0/Documents/Through\%20the\%20gateway.p df

Coates, S. (2016) Unlocking Potential: A Review of Education in Prison, London: Ministry of Justice

Crewe, B. (2007) 'Power, adaptation and resistance in a late-modern men's prison', British Journal of Criminology 47: 256-275 
Crewe, B. (2009) The Prisoner Society: Power, Adaptation and Social Life in an English Prison, Oxford: Oxford University Press

Foucault, M. (1977) Discipline and Punish: the Birth of the Prison, London: Penguin

Garland, D. (1997) 'Governmentality' and the problem of crime: Foucault, criminology, sociology, Theoretical Criminology 1(2): 173-214

Goffman, E. (1961) 'On the characteristics of total institutions: the inmate world' in Cressey, D. (ed.) The Prison: Studies in Institutional Organisation and Change, New York: Holt, Rinehart \& Winston

Grant, E. and Jewkes, Y. (2014) '"More Important than guns or grog": The role of television in the lives of Australian Aboriginal prisoners', Current Issues in Criminal Justice, 25(2): 667683

Helsper, E.J. (2011) LSE Media Policy Brief 3. Available online: http://www.Ise.ac.uk/media\%40lse/documents/MPP/LSEMPPBrief3.pdf

Helsper, E. J., \& Eynon, R. (2013) 'Distinct skill pathways to digital engagement', European Journal of Communication, 28(6), 696-713

Jewkes, Y. (2002) Captive Audience: Media, Masculinity and Power in Prisons, Cullompton: Willan

Johnson, R. (2005) 'Brave new prisons: the growing social isolation of modern penal institutions' in A. Liebling and S. Maruna (eds.) The Effects of Imprisonment, Cullompton: Willan

Knight, V. (2015) 'Some observations on the digital landscape of prisons today', Prison Service Journal no. 220, 3-9

Knight, V. (2016) Remote Control: Television in Prison, London: Palgrave Macmillan

Meyrowitz, J. (1985) No Sense of Place: The Impact of Electronic Media on Social Behaviour, Oxford: Oxford University Press

Meyrowitz, J. (2005) 'The Rise of Glocality: New Senses of Place and Identity in the Global Village', pp. 21-30 in K. Nyiri (ed.) A Sense of Place: The Global and the Local in Mobile Communication. Vienna: Passagen Verlag 
Moores, S. (2007) 'Media and Senses of Place: On Situational and Phenomenological Geographies', LSE electronic working paper No 12. Available online:

http://www.Ise.ac.uk/media@Ise/research/mediaWorkingPapers/pdf/EWP12.pdf

Morley, D. and Robins, K. (1995) Spaces of Identity: Global Media, Electronic Landscapes and Cultural Boundaries, London: Routledge

Reisdorf, B. C., Axelsson, A. S., and Maurin, H. (2012) 'Living Offline-A Qualitative Study of Internet Non-Use in Great Britain and Sweden', Selected Papers of Internet Research, 2. Available online: http://spir.aoir.org/index.php/spir/article/view/10

Scannell, P. (1996) Radio, Television and Modern Life, Oxford: Blackwell

Schaupp, L. C., \& Bélanger, F. (2013) 'The value of social media for small businesses', Journal of Information Systems 28(1): 187-207

Selwyn, N. (2004) 'Reconsidering Political and Popular Understandings of the Digital Divide', New Media \& Society 6(3): 341-362

Sparks, R, Bottoms, A. E. and Hay, W. (1996) Prisons and the Problem of Order, Oxford: Oxford University Press

Sykes G. (1958) The Society of Captives: A Study of a Maximum Security Prison Princeton University Press New Jersey

Zillien, U., Hargittai, E. (2009) Digital Distinction: Status-Specific Types of Internet Usage', Social Science Quarterly 90(2): 274-291 